Journal of Southeast Asian

\title{
Looking Gran Torino in the Eye: A Review
}

Ly Chong Jalao

jalao@umail.ucsb.edu

Follow this and additional works at: https://docs.lib.purdue.edu/jsaaea

Part of the Asian American Studies Commons

\section{Recommended Citation}

Jalao, Ly Chong (2010) "Looking Gran Torino in the Eye: A Review," Journal of Southeast Asian American Education and Advancement: Vol. 5 : Iss. 1, Article 15.

DOI: $10.7771 / 2153-8999.1016$

Available at: https://docs.lib.purdue.edu/jsaaea/vol5/iss1/15

This document has been made available through Purdue e-Pubs, a service of the Purdue University Libraries. Please contact epubs@purdue.edu for additional information.

This is an Open Access journal. This means that it uses a funding model that does not charge readers or their institutions for access. Readers may freely read, download, copy, distribute, print, search, or link to the full texts of articles. This journal is covered under the CC BY-NC-ND license. 


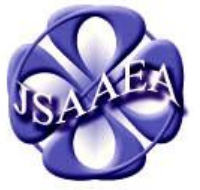

Volume 5 (2010)

\section{Journal of Southeast Asian American \\ Education \& Advancement}

WWW.JSAAEA.org
A peer-reviewed

scholarly journal

published by the

National Association

for the Education \&

Advancement of

Cambodian, Laotian, and Vietnamese Americans (NAFEA)

\section{Film Review}

Eastwood, C., Gerber, B., \& Lorenz, R. (Producers), \& Eastwood, C. (Director). (2008). Gran Torino [Motion Picture]. United States: Warner Bros.

\section{Looking Gran Torino in the Eye: A Review}

\section{by Ly Chong Thong Jalao}

Even before Clint Eastwood's Gran Torino was released to critical acclaim and commercial success in 2009, the film was already a heated topic of discussion in the many Hmong communities scattered throughout America. The producers had made the decision to audition Hmong actors, and Hmong input was sought to some extent. Heeding the casting calls, many Hmong were excited at the prospect of participating in a major Hollywood project, at putting "Hmong" on the map, as some would say. Others were apprehensive given Hollywood's past treatment of Asian American communities. When details emerged that the plot would involve Hmong gang members, the specter of violent Hmong men rampaging through neighborhoods and killing white Americans reared its ugly head. The film came shortly after the word Hmong had been displayed prominently in the national and international news in conjunction with cases of armed menace: the highly sensationalized trial of Chai Soua Vang, a Hmong man convicted, in 2005, of murdering six white hunters in the Wisconsin woods; and the 2007 arrest of General Vang Pao, a central figure in the Hmong community and former CIA point man for the Vietnamera Secret War, who was accused of plotting the violent overthrow of the Communist government of Laos. It was in such a charged atmosphere that Gran Torino was produced and released. The fear among many Hmong was that the film would exacerbate the stereotyping of Hmong people, especially Hmong men, as naturally violent. Upon its release, the film confirmed that fear, however allayed it may have been by the fact that, this time, only one white person was murdered.

Despite Hmong involvement in the production of Gran Torino, from actors to production assistants to "cultural consultants," the film insists on genericizing Hmong Americans into some vaguely Asian group. In one scene, a Hmong grandmother is shown out-spitting Clint Eastwood's character, Walt Kowalski, a sight not so much disgusting as inaccurate, and hence unsettling for Hmong viewers since Hmong people have never chewed betel nut, even in Asia. In scene after scene, Hmong culture is reified and paraded for the sake of parading, as when a Hmong shaman approaches Walt to offer him the kind of mystical insight usually proffered by

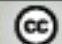

SOMERIGHISRESERVED Readers are free to copy, display, and distribute this article, as long as the work is attributed to the author(s) and the Journal of Southeast Asian American Education \& Advancement, it is distributed for noncommercial purposes only, and no alteration or transformation is made in the work. More details of this Creative Commons license are available at http://creativecommons.org/licenses/by-nc-nd/3.0/. All other uses must be approved by the author(s) or JSAAEA. 
Kung Fu Masters so familiar to American audiences now. For a Hmong American audience steeped in its own culture in flux, the choreographed and yet static displays of "Hmong culture" in Gran Torino appear unhinged. The experience of watching the film is akin to that of watching dancers who look familiar but are out of sync: The moves are performed and the poses are struck mostly correctly, but the timing is so off that the result is a feeling of disjunction, of malrecognition. This is no doubt one of the reasons why some Hmong viewers claim that Gran Torino is a comedy - a comedy of errors, one might add.

The film itself is a rather tired Hollywood melodrama. It recycles the theme of redemption and repackages it for our era of change and racial transition. Walt Kowalski, a Korean War veteran with a guilty conscience, is the sort of racist we can all come to love because, as the film teaches us, deep down, he's really a nice guy. As a stubborn holdover from white suburban flight, Kowalski watches as his neighborhood is overrun by Asians and other minorities. Within the racialized landscape of America, this enables him to become a reluctant father figure to the "newcomers" and to guide them through the intricacies of becoming Americans. This is especially true for Thao, Walt's teen Hmong neighbor whom he takes under his wing. The film follows the relationship between the young man and his older mentor. Walt dispenses advice on how to become a man as freely as he utters racial epithets. In one telling scene, he takes Thao to the local barbershop in order to "man him up" by teaching him the finer points of a proper racist and sexist banter. The barber, an old acquaintance of Walt, plays along and, at one point and seemingly in jest, brandishes a concealed shotgun at Thao to show his disapproval of the young "trainee's" lack of macho and racist etiquette. But the scene is awkward. The lively banter is disturbed by the image of this older white man pointing a shotgun at an unarmed Hmong youth. This standoff will be replayed in reverse at the end of the film, before Walt is gunned down by a group of Hmong gang members.

The real carrier of violence, the film suggests, lies not in language but in "real" acts. The Hmong gang members harass Thao and his sister, Sue, throughout the film and exchange threats with Walt, prodding him to become the siblings' protector. But, it seems, unlike Walt's innocuous racism and the barber's pedagogic shotgun threat, the gang members' violence is consummated when they rape Sue in retaliation for Thao's unwillingness to join them, as well as for Walt's intervention on behalf of the youth.

Gran Torino could almost have been a coming-of-age story about this Hmong teenager, but the redemption of Walt Kowalski takes precedence and turns Thao into a plot device and the vehicle for salvation. Walt's salvation, that is. Likewise, Thao's strong-willed sister starts off as a tough young woman but ends up as a broken victim of intra-ethnic violence. It is this act of violence that leads to the film's denouement, when Walt sacrifices himself by "tricking" the gang into shooting him, an unarmed man, and thereby triggering the Hollywood cliché of the police arriving on the scene to handcuff and drag off the bad guys once the deed is done. Presumably, the gang is off to jail and Thao and his family can now live safely ever after.

In all of this, the two Hmong siblings exist in a universe where Hmong adults are either dead (their father), present but muted by their limited English skills (their mother and grandmother), or relegated to the status of props (the curious elderly Hmong neighbors). The only other major Hmong characters are the gang members, who come off as kids trying to look tough. They also embody a line uttered by Sue so forthrightly that it can only be a truism, but which many Hmong viewers found to be the most injurious moment in the film: "Hmong girls over here fit in better. The girls go to college. The boys go to jail."1 The overall effect is that of an infantilized Hmong community incapable of fending for itself and severely lacking in the 
proper tools for success in America, as epitomized by Thao's self-deprecation to Walt that, "I don't have a job, a car, or a girlfriend." In other words, he has none of the trappings of successful American masculinity.

For a Hmong audience well versed in the mythology of the Vietnam War, the plot of Gran Torino uncannily follows the broad outline of U.S. intervention in Southeast Asia. We have in Walt the well-intentioned American who lost his innocence in a foreign war, and we have in Thao an effeminate Asia in need of being saved from itself and from pathological interethnic strife. When Walt's bullet-ridden body falls to the ground at the end of the film, his Christ-like posture in death assures us that while salvation is at hand for this American veteran, for his Hmong counterparts, the path toward legitimacy and legibility in America has been hallowed and made safe. But this comes at a cost to the Hmong.

For many of the Hmong who saw Gran Torino, the most believable part of the film occurs when the gang members kill Walt at the end. Believable not because the film's portrayal of Hmong youths as violent and predatory gang members depicts an essential reality, but because the gang members are the only characters in the film who exhibit the kind of agency that approximates the real possibilities and precariousness of life in a Hmong American community. That is to say, despicable as they appear on screen, the Hmong gang members defy the very disciplining the film's plot imposes on Thao. Yes, Thao is purportedly promised entrance into full-blown American society through Walt's gift of his 1972 Gran Torino at the end. And yes, if not necessarily the other traditional racial marker of Americanization, namely, a white American girlfriend, Thao at least gets Walt's dog, whom we see riding shotgun with the dreamy youth as they ride into a metaphorical sunset in the last shot. But for many younger Hmong Americans, the gang members' deviation from middle-class propriety becomes a locus through which America is made contestable once again, and whereby they do not have to adhere to a moral center defined by rigidly prescribed racial and gender roles.

Of course, therein also lies the divided subjective response to the film by many in the Hmong community. In the aftermath of the sensationalized and hyper-visible cases mentioned above, and in light of the Hmong's relegation to the status of perpetual foreigners and warriorsquasi-genetically predisposed to violence - the predicament most Hmong viewers find themselves in, however inchoately, is that the more liberating and true-to-their-experience part of the film is also the very negative stereotype which condemns them to life as perpetual aliens. In the process of exploiting and reifying the lives and stories of other people, Hollywood imposes the injunctions of a law-abiding, middle-class life for Hmong people while at the same time also avoiding or eliding the very extra-legal forms of violence it depends on, beginning with America's amnesic and bellicose relationship with Southeast Asia, and including racial and other forms of discursive violence committed upon the Hmong and other minoritized groups. The result is that, for many Hmong, the choice given in the film is a false one: Either accept the gender and racial hierarchies and protocols for success as laid out in Walt's racist universe, and for which He sacrificed himself; or remain among the wretched of the earth, forever doomed to the inner cities of America.

Given that, it is no wonder that Elvis Thao, one of the Hmong actors who played a gang member in the film, was able to celebrate gleefully in a widely circulated e-mail, after the release of the film, that he "shot Clint." This image of Hollywood icon Eastwood-and not merely the character of Walt Kowalski-brought down by an anonymous Hmong gang member shortcircuits the proper boundaries between the film's fictional status and its effects in the real world. The statement correctly intuits that the way out of a false choice is to choose neither and, instead, 
to shoot through the power asymmetries and reveal how such a flimsy fiction as Gran Torino is supported by a massive network of legal and extra-legal violence.

From this perspective, the injurious and distorting aspects of the film paradoxically also afford a pleasure derived from knowing, or sensing, that the film is in fact a comedy of errors, and that the joke is, if not entirely, at least partly on Hollywood. For Hmong Americans, the legacy of Gran Torino will always be a complicated matter. The film marks a cultural homecoming of sorts, but one in which all the previous tensions and repressed histories have not been worked through on an equal footing by all parties involved. For many Hmong individuals, the film's refusal to explore the intertwined and complicated history of the Hmong and the United States is seen as both a cop-out and a challenge for the Hmong to tell their own story, on their own terms.

\section{End Notes}

${ }^{1}$ This "truism," immediately so in need of being unpacked and contested, was startlingly well received in some circles, even Asian American ones. In an online review of Gran Torino, for instance, the Media Action Network for Asian Americans, a watchdog organization whose concern is precisely the negative stereotyping of Asian Americans in Hollywood, gives the film a free pass on this issue. Praising Gran Torino for taking its "educational responsibility seriously" through detailing the Hmong's "current sociocultural difficulties," it gives precisely this instance as illustration of Hmong urban "realities." Symptomatic of Gran Torino's power to co-opt even the most vigilant of critics, MANAA's failure lies in its inability to suture the stereotyping of a largely ignored sub-group, the Hmong, with the larger history of an embattled Asian America constantly fighting against this kind of discursive violence whose effects are all too real; instead, the organization misrecognizes Hmong as something other to, and presumably more dysfunctional than, mainstream and voiced Asian America. MANAA's review, as well as the film itself, is aided in that omission by the relative invisibility of Hmong Americans, even within an Asian American context.

\section{Acknowledgements}

I would like to thank Louisa Schein and the other members of the Critical Hmong Studies Collective, as well as Va-Megn Thoj, for their critical engagement with the ideas expressed in this review. The points raised here are part of an ongoing series of conversations and forums between the Collective and other Hmong scholars and activists, as well as the Hmong community at large, including the many Hmong individuals who were involved in making Gran Torino.

\section{About the Reviewer}

Ly Chong Thong Jalao is a Ph.D. student in English at the University of California, Santa Barbara. His research focuses on the colonial legacy of the French and the United States after the first and second Indochina conflicts. He is particularly interested in how Hmong American literary and cultural productions intersect with that larger history. He is also a member of the Critical Hmong Studies Collective, a group of concerned scholars and activists working on political, cultural and academic issues involving the Hmong. 


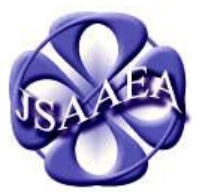

Volume 5(2010)
Journal of Southeast Asian American Education \& Advancement WWW.JSAAEA.org
A peer-reviewed scholarly journal published by the National Association for the Education \& Advancement of Cambodian, Laotian, and Vietnamese Americans (NAFEA)
Editor

Dr. Wayne E. Wright

University of Texas, San Antonio

Associate Editors

Dr. Chhany Sak-Humphry

University of Hawaii

Dr. KimOanh Nguyen-Lam

California State University, Long Beach

Book Review Editor

Vichet Chhuon

University of Minnesota

Creative Works Editor

Bryan Thao Worra

Lao Assistance Center

Editorial Assistant

Kathleen Langham

University of Texas, San Antonio

Comments and questions for the editorial staff may be directed to jsaaea@ lists.sis.utsa.edu

\section{Editorial Review Board}

\author{
Dr. Carl L. Bankston III \\ Tulane University \\ Dr. Phala Chea \\ Lowell Public Schools \\ Dr. Changming Duan \\ University of Missouri, Kansas City \\ Dr. Nancy H. Hornberger \\ University of Pennsylvania \\ Dr. Peter Nien-Chu Kiang \\ University of Massachusetts, Boston \\ Dr. Stacey Lee \\ University of Wisconsin, Madison \\ Dr. Sue Needham \\ California State University, Dominguez Hills
}

Dr. Pollie Bith-Melander

Asian and Pacific Islander Wellness Center

Dr. George Chigas

University of Massachusetts, Lowell

Dr. Sophal Ear

U.S. Naval Postgraduate School

Dr. Samlong Inthaly

Minneapolis Public Schools

Dr. Kevin K. Kumashiro

University of Illinois, Chicago

Dr. David Chanpannha Ley

Montgomery County Public Schools

Dr. Bic Ngo

University of Minnesota 
Journal of Southeast Asian American Education and Advancement, Vol. 5 [2010], Iss. 1, Art. 15

Jalao-Film Review of Gran Torino

Dr. Max Niedzwiecki

Daylight Consulting Group

Dr. Clara Park

California State University, Northridge

Dr. Loan T. Phan

University of New Hampshire

Dr. Karen Quintiliani

California State University, Long Beach

Dr. Fay Shin

California State University, Long Beach

Dr. Yer J. Thao

Portland State University

Dr. Khatharya Um

University of California, Berkeley

Dr. Terrence G. Wiley

Arizona State University
Dr. Leakhena Nou

California State University, Long Beach

Dr. Mark Pfeifer

Texas A\&M University, Corpus Christi

Dr. Bounlieng Phommasouvanh

Minnesota Department of Education

Dr. Kalyani Rai

University of Wisconsin, Milwaukee

Dr. Nancy J. Smith-Hefner

Boston University

Dr. Myluong Tran

San Diego State University

Dr. Linda Trinh Vo

University of California, Irvine

Dr. Zha Blong Xiong

University of Minnesota

Dr. Kou Yang

California State University, Stanislaus

\section{Doctoral Student Editorial Review Board}

\section{Keo Chea}

University of Pennsylvania

Annie BichLoan Duong

San Joaquin County Office of Education

\section{Ha Lam}

Arizona State University

Giang Pham

University of Minnesota

Rassamichanh Souryasack

University of California, Santa Barbara

Loan Tran

University of California, Santa Barbara

Phitsamay Sychitkokhong Uy

Harvard University
Loan Dao

University of California, Berkeley

Peter Tan Keo

Columbia University

Ravy Lao

University of California, Santa Barbara

Vanna Som

Harvard University

Layheng Ting

State University of New York, Albany

Tinou Tran

University of Houston, Texas

Yang Sao Xiong

University of California, Los Angeles 